\title{
Dissemination on Rice's New High Yielding Variety Through Demonstration Farming of Jajar Legowo Technology in East Java
}

\author{
Tri Sudaryono \\ Researcher at Assessment Institute for Agricultural Technology \\ Malang, East Jawa, Indonesia
}

\begin{abstract}
Agricultural Research Agency has innovated Integrated Crop Management (ICM) of lowland rice. This innovation has been adopted and developed by the General of Food Crop Directorate and implemented in the form of Field School. The constituent technology components of ICM continues to be refined over time. Various components of the resulted technology are assembled into a technology package called Jajar Legowo Super of Rice Technology. The intactly application of this technology by farmers accompanied by intensive facilitation is believed to be able to produce yield at least 10 tons of Drain Grain Harvest (DGH)/ha in each season, compared to the yield of rice cultivated by farmers which is only about 6 tons of DGH/ha. Accelerating the dissemination of Rice's New Superior Varieties through Demonstration Farming (Demo farm) of Jajar Legowo Super Technology in East Java was conducted in Central Sadar Village, Mojoanyar Subdistrict, Mojokerto Regency involving Mardi Tani Farmer Group. The activity was held at Dry Season II (June November 2016). Through this activity, it is expected to accelerate the spread and the increasing implementation of rice farming technology adoption through the approach of Jajar Legowo Super which has an impact on the increasing efficiency of farming. Results show that the use of Certified Superior Seed Varieties (CSSV) through demo farm of Jajar Legowo Super increases productivity between $12.26-32.03 \%$, improves farmers' efficiency and income, and generates about 25 tons of Extention Seed (ES) and Stock Seed (S) paddy seeds. In addition, from this activity it is confirmed that adopting the technology components of Jajar Legowo Super by farmers increases significantly if compared to both before and after demo farm. The highest adoption increase about $60 \%$ is shown in components using Rice Field Test Kit (RFTK) and biological fertilizers.
\end{abstract}

Keywords: Dissemination, Jajar Legowo Super, Rice, Technology

\section{INTRODUCTION}

Food crop commodities have a fundamental role to meet food needs. Reliability in rice supports the development of food crop subsector and plays an important role to achieve food security [1]. It also greatly contributes to the national Gross Domestic Product (GDP) [2][3].

In 2015-2017, the government has instructed the achievement of rice self-sufficiency through Special Effort (SE) in all provinces of Indonesia. To achieve these targets, the most realistic effort is through increasing productivity, regarding that the increasing harvest area is difficult to expect since in the dry season, low irrigation water debit becomes an important consideration. If the platform of production is the productivity rise, then the application of recommended technology is a must. In such correlation, the technology with ICM approach is believed to significantly increase the productivity. It is confirmed through the increase of rice productivity collected from all East Java farmer groups who applied Agency for

Correspondence address:

Tri Sudaryono

Email : trissdr@yahoo.com

Address : AIAT, Jl. Raya Karangploso Km 4 Malang, East Jawa, Indonesia
Agricultural Research and Development's (Balitbangtan) innovation technology which was able to increase the productivity up to $15 \%$ by the end of 2014 [4].

One of the most rapid adoptable technologies is superior variety. Since 1967-2009 the released rice in Indonesia has been more than 250 varieties and $90 \%$ of varieties in circulation is produced by Agricultural Research Agency [5]. Using the improved varieties can provide some positive effects including: substitute of viral strains and improvement of disease resistance. Based on the atlas of spreading Superior Rice Varieties of Agricultural Rice Research Agency in 2012 it is known that hitherto there are 68 varieties of rice paddy of Agricultural Research Agency existing in the field. It showed that the existence of high yielding rice varieties in the region is closely related to the suitability of agroecosystem areas where Certified Superior Seed Varieties (CSSV) are developed and accepted in accordance with local customs and culture. However, hitherto Ciherang varieties still dominate with the availability of $40-45 \%$, followed by Mekongga 12\%, IR 64 10\%, and the rest are other varieties including INPARI and others [6]. These directions and information can serve as the bases for developing and disseminating CSSV more effectively and 
efficiently [5]. The rice cultivation technology with ICM which are most widely used are: CSSV (67.5\%), organic fertilizer $(57.8 \%)$, balanced fertilization $(49,046)$ and pest control with Integrated Pest Management (IPM) concept $(49.03 \%)$ and ability to increase rice productivity up to $21,03 \%$ nationally [7].

The availability of qualified seeds becomes very strategic as a main support to achieve success in plant cultivation [8]. Seeds have a very strategic position in agricultural development, since qualified seeds make the most significant contribution to increase crop productivity. The World Bank's research results conclude CSSV is the largest single contributor (16\%) to increase rice production, followed by irrigation (5\%) and fertilizer (4\%). The interaction amongst CSSV, irrigation, and fertilizer can increase productivity up to $75 \%$, while the contribution from plantation expansion is only $25 \%$. [9]. stated that the role of CSSV rice seed is inseparable from the role of seed producers and the national seed system. Data from the 1970s to the 2000s showed that the increase in the number of CSSV is proportional to the increase of national rice production, where the rate of increase in rice production is in line with the increasing rate of population [10].

In order to support the production increase of strategic commodities, site-specific technology assemblies are required. In addition to productivity increase, the technology must also be able to improve farming efficiency in order to increase farmer profit as well as to sustainably optimize agricultural resources. Various technological components need to be examined for their efficiency, effectiveness, validity and synergy on one component with another for arrangement of location specific technology assembly in the framework of Integrated Crop Management (ICM) of each strategic commodity. Method of cultivation of jajar-legowo is 2:1 is reported to be able to increase rice yield around $30 \%$. [11] suggested that recommending ICM technology needs to see biophysical and socioeconomic factors and based on scientific reasoning. The effectiveness of each component needs to study, either per item or interaction/synergy among technology components in ICM.

In 2008 Balitbangtan has innovated Integrated Crop Management (ICM) on rice field. This innovation was then adopted and developed by the Directorate General of Food Crops and implemented in the form of ICM Field School
[12]. Constituent technology components of ICM continue to be refined over time. Resulted various technology components are assembled into a technology package called "Jajar Legowo Super Rice Technology" [13].

Among CSSVs introduced in East Java, they have different potential outcomes in several locations. Inpari 14 and Inpari 19 varieties have good potential result [14]. From 29 regencies, CSSV's display performance and ICM application showed that the average yield of variety Inpari 14 was $6.27 \mathrm{t} / \mathrm{ha}$, the yield of variety Inpari 16 was $6.68 \mathrm{t} / \mathrm{ha}$ as the highest yield followed by the grain yield of varieties Inpari 18 and 19 [15]. Variety Inpari 18 has high yield potential, however, it is relatively susceptible to Brown Planthopper attack. From the display location of harvested CSSV rice, it showed that variety Inpari 18 produces a wide variety of grains, ranging from 3.44 to $12.8 \mathrm{t}$ /ha of harvest dry grain [16].

The research aimed to: a) accelerate the dissemination of rice cultivation technology of jajar legowo super and CSSV rice of Balitbangtan, b) increase the adoption of jajar legowo super and CSSV technology to increase rice production in East Java; c) increase the production of CSSV seeds as logistical support to enhance rice production activities.

\section{METHODOLOGY}

\section{The scope of activities}

The study was conducted on a participatory principle in farmers' lands and it involved farmer groups, including the following scope of activities:

1. Identification of needs/socialization and advocacy of accelerated dissemination activities of CSSV rice and jarwo super technology demo farm for related stakeholders

2. Application of jarwo super technology and CSSV as Balitbangtan results in demo farm form

3. Technical introduction on fertilizer manufacture, biological pesticide, use of RFTK

4. Introduction on the use of alsitan (transplanter and combine harvester)

5. Dissemination activities (conducted with various dissemination media assessed in accordance with the location of activities in Mojokerto Regency, East Java) and the measurement on the effectiveness of dissemination activities.

6. Field meeting by involving relevant stakeholders. 


\section{Materials}

Materials for this activity included CSSV seeds of Inpari 30, Inpari 32 and Inpari 33, Ponska, Urea, ZA, organic fertilizers, pesticide, M-Dec: organic material remodeling bio-activator, Biological Fertilizer: Agrimeth; Plant-disturbing organism (Pest) control agents (pheromones, biopesticides).

\section{Setting of Activity Implementation}

Activities on 10 ha demo farm were located in Sadar Tengah Village, Mojoanyar District, Mojokerto Regency, East Java Province. The location was on 100 ha rice field approximately, with rice-rice-rice cropping pattern. The implementation of demo farm cooperated with Mardi Tani Farmer Group, which has about 30 members. Farmers participating in demo farm were quite responsive to new technology. The source of irrigation came from technical irrigation the year. This demo farm area had just been harvested, the hay stump was still available in the field, not flooded, easy to visit and available for field meeting.

This activity was carried out for 6 (six) months by following the planting time in dry season started from June to November 2016.

\section{Data collection}

The collected data includes:

1) Total use of production input and use of labor at each stage of seed production (Farm Record Keeping/FRK)\

2) Plant growth (number of tillers, plant height and chlorophyll meter/SPAD) at several growth phases

3) Components of yield (number of panicles per clump, number of grains per panicle, percentage of grain contents, and weight of 1000 grains)

4) Results (Dry Grain Harvest (DGH) and Dried Milled Grain (DMG)) water, sufficient to irrigate rice fields throughout

Table 1. Comparison of Existing and Jarwo Super Technology

\begin{tabular}{|c|c|c|}
\hline Activities & Existing Technology & Jarwo super \\
\hline Cropping pattern & Rice-rice-fallow (in early rainy season) & Rice-rice-rice \\
\hline Production & $63 \mathrm{ku} / \mathrm{ha}$ & $80-90 \mathrm{ku} / \mathrm{ha}$ \\
\hline Land cultivation & Yes & Yes \\
\hline - Tillage & 2 weeks before planting & 2 weeks before planting \\
\hline - Tillage equipment & Tractor & Tractor \\
\hline - Straw utilization & no & yes \\
\hline Number of seed / ha & $60 \mathrm{~kg}$ & $30 \mathrm{~kg}$ \\
\hline Varieties & Ciherang, Way apo buru & Inpari 30, Inp 32 and $\operatorname{Inp} 33$ \\
\hline Class of seed & SS & SS \\
\hline Nursery Size & $20 \mathrm{~m} 2 / \mathrm{bag}$ & $20 \mathrm{~m} 2 / \mathrm{bag}$ \\
\hline Cropping system (jarwo/non) & Non/jarwo & Jarwo 2:1 \\
\hline Plant Spacing & $25 \times 25 / 35 \times 20 \times 20$ & $(20 \times 10 \times 40)$ \\
\hline Nursery method & regular & regular \\
\hline Age of transplanting & 20-30 DAS & $15-20$ DAS \\
\hline RFTK/Lab Analysis & no & yes \\
\hline NPK Phonska (kg/ha) & 300 & 300 \\
\hline Urea (kg/ha) & 200 & 100 \\
\hline $\mathrm{ZA}(\mathrm{kg} / \mathrm{ha})$ & - & 100 \\
\hline ZnSO4 & no & yes \\
\hline Organic fertilizer (kg/ha) & 500 & 500 \\
\hline Dosage of fertilizer 1 & 150 kg NPK 100 Kg Urea & 200 kg NPK 50 kg Urea 50 kg ZA \\
\hline Dosage of fertilizer 2 & 150 NPK & 100 NPK 50 kg Urea 50 kg ZA \\
\hline Dosage of fertilizer 3 & $100 \mathrm{~kg}$ Urea & - \\
\hline Weeding 1 & Manual & Manual \& weed tool \\
\hline Weeding 2 & Manual & Manual \& weed tool \\
\hline Irrigation (intermittent/non) & no & no \\
\hline Vegetable pesticide & no & yes \\
\hline Inorganic pesticide & yes & yes when attacks above economic threshold \\
\hline Harvesting tools & sickle-power thresher & sickle-power thresher \\
\hline
\end{tabular}

DAS: Days after Sowing 
5) Agricultural input and output data through FRK used to analyze farming practices

6) Farmers' preferences to the crops' growth, yield as well as the taste of cultivated rice varieties

\section{RESULT AND DISCUSSION}

1. Existing Condition of Research Sites and Implementation of Technology

Mojoanyar is one of rice center sub-districts in Mojokerto regency. The total land area reached 647 ha, where the average crop productivity of the sub-districts was $76 \mathrm{ku} / \mathrm{ha}$ (demo plot of jajar legowo and ICM in 2015); meanwhile, the average crop productivity without applying jajar legowo and ICM was 3 $\mathrm{ku} / \mathrm{ha}$. The area of rice cultivation in Sadar Tengah village was 35 ha with rice-rice-fallow cropping pattern which occurred in the beginning of November-December rainy season period. The rice potential land could be cultivated three times, but the area was mice endemic and often appeared acidity. Eventually, farmers preferred to leave the land to avoid crop failure. Detailed comparison of existing and jarwo super technologies is presented in Table 1.

\section{Performance Indicators \\ a. Crop Productivity}

Field observations showed that Ciherang existing varieties grown without applying jarwo super technology have the lowest yield compared to other varieties grown with jarwo super technology. Inpari 30 Ciherang Sub 1 increased rice production by $29.3 \%$, Inpari 32 by $32.03 \%$ and Inpari 33 by $12.26 \%$ (Table 2). In addition, based on the production of certified seeds from demo farm activities until November 2016, the number of prospective seeds that had been processed was $34.964 \mathrm{~kg}$ for Inpari 30 Ciherang sub 1 and Inpari 32 varieties.

CSSV productivity (Inpari 30, Inpari 32 and Inpari 33) was higher than that of Ciherang variety, one of which was because CSSV had better growth since the third seed phase. Better seed growth was due to seed treatment by Agrimeth biological fertilizer. Seeds treated with Agrimeth showed more roots than Ciherang varieties which were not treated with Agrimeth.

\section{b. Organoleptic Test}

One element in PVS (Participatory Variety Selection) method, namely farmers' preference for adopting a new variety of rice is the rice taste. As the main meal, an ability to develop a variety is especially in terms of taste. Even though CSSV has an agronomic superiority, when it is not favored on its primary product, it can be assured that the new variety will be difficult to develop. Therefore, demo farm of jarwo super took organoleptic test CSSV Inpari 30 Ciherang Sub 1, Inpari 32, and Inpari 33.

Table 2. Productivity of CSSV and comparison

\begin{tabular}{|c|c|c|c|c|c|c|c|}
\hline Varieties & $\mathrm{TT}(\mathrm{cm})$ & $\begin{array}{l}\text { Number } \\
\text { of tiller } \\
\text { (stem) }\end{array}$ & $\begin{array}{l}\text { Length of } \\
\text { panicle } \\
\text { (cm) }\end{array}$ & $\begin{array}{l}\text { Number } \\
\text { of filled } \\
\text { grain per } \\
\text { panicle }\end{array}$ & $\begin{array}{l}\text { Number of } \\
\text { empty grain } \\
\text { per panicle }\end{array}$ & $\begin{array}{l}1000 \text { grains } \\
\text { (gram) }\end{array}$ & $\begin{array}{c}\text { Crop } \\
\text { yield } \\
\text { (ton/ha) }\end{array}$ \\
\hline Inpari 30 & $109,20 \mathrm{a}$ & $20,90 \mathrm{a}$ & $19,40 \mathrm{~b}$ & $106 a b$ & $7,40 \mathrm{c}$ & $29,40 \mathrm{a}$ & $8,92 \mathrm{a}$ \\
\hline Inpari 32 & $109,50 \mathrm{a}$ & 20,60 a & $20,94 \mathrm{~b}$ & $108 a$ & $11,70 \mathrm{bc}$ & $28,40 a b$ & $9,27 \mathrm{a}$ \\
\hline Ciherang & $1100,6 \mathrm{~b}$ & $13 \mathrm{~b}$ & $17,40 \mathrm{c}$ & 87,5 b & $17,50 a b$ & $23,90 \mathrm{c}$ & $6,30 \mathrm{c}$ \\
\hline Inpari 33 & 106,8 a & $11,90 \mathrm{~b}$ & 25,05 a & 119 a & $23,20 \mathrm{a}$ & $27,73 \mathrm{~b}$ & $7,18 \mathrm{~b}$ \\
\hline
\end{tabular}

Description: Figures in the same column accompanied by the same letter show no significant difference based on $5 \%$ BNT test

Table 3. Results of Organoleptic Test 3 of CSSV Rice

\begin{tabular}{lccc} 
& Parameter & Treatment & \\
& INPARI 30 & INPARI 32 & INPARI 33 \\
\hline Colour & $2,966 \mathrm{c}$ & $3,724 \mathrm{~b}$ & $4,448 \mathrm{a}$ \\
Test & $3,00 \mathrm{~b}$ & $3,724 \mathrm{a}$ & $3,793 \mathrm{a}$ \\
Aroma & $3,034 \mathrm{~b}$ & $3,414 \mathrm{~b}$ & $3,862 \mathrm{a}$ \\
Texture & $3,000 \mathrm{~b}$ & $3,966 \mathrm{a}$ & $3,897 \mathrm{a}$ \\
Gloss & $2,621 \mathrm{c}$ & $3,517 \mathrm{~b}$ & $4,172 \mathrm{a}$ \\
Preference & $3,103 \mathrm{~b}$ & $3,897 \mathrm{a}$ & $4,000 \mathrm{a}$ \\
\hline
\end{tabular}

Description: Figures on the same line accompanied by different letters showed significant difference based on 5\% BNT test 
From the test result, the most preferred organoleptic variety was Inpari 33 (Table 3).

\section{c. Farm Income}

Jarwo Super technology was proved to be able to improve farmers' income even though the cost of its planting technology doubly increased when compared to tile-modeled planting. In addition, the overall cost was lower than the cost of nonjajar legowo super (Table 4). Reducing cost laid in the application of inorganic fertilizer application and the cost of using seed. $\mathrm{B} / \mathrm{C}$ ratio with jarwo super technology is expected to continue to increase along with the rise of soil fertility; thus, it reduces the cost of production inputs such as inorganic fertilizers.

\section{d. Institutional Performance}

Demo farm of jarwo super increases the intensity of group meetings, especially to discuss each stage of jarwo super's activities. If the meeting as the farmer group's habit is held once a month, then it increases weekly. The highest intensity occurs at the beginning of planting, because there are pest attacks both from brownplanthopper and mice. Farmer groups also independently learn about the provision of superior seeds, even though the demo farm results will be certified into seed. Since none of the farmer group members has a certificate of breeder, the future members are guided to be able to independently produce seeds. The enthusiasm of members is primarily during the rouging practice with local Supervisors of Plant Seed, because such expertise is one of basic abilities to be a seed producer.

\section{Dissemination Activities}

The dissemination method applied in this study used demonstration area (demo farm) to accelerate technology, since each farmer's action to apply the technology is limited by nontechnical factors, both social and economic ones [17]. Targets of this dissemination activity were farmers, farmer groups, farmer group association, officers, and entrepreneurs in agriculture. Characteristics of farmers and their households also determine the level of adoption of introduced jarwo super technology. Commodities cultivated by farmers also vary. In addition to farming rice, farmers also gardening, breeding, trading and other businesses. They are the main actors in applying innovation of jarwo super rice. Farmers' active participation and involvement will encourage the acceleration of technology dissemination/adoption as well as the main capital for the successful increase of rice production.

Table 4. Analysis of Farming

\begin{tabular}{|c|c|c|}
\hline Components & Existing x (Rp.1.000) & Jarwo Super x (Rp.1.000) \\
\hline \multicolumn{3}{|l|}{ Expense } \\
\hline a. Production facilities & & \\
\hline - Seed & 660 & 240 \\
\hline - $\quad$ Fertilizer & 1.500 & 1.650 \\
\hline - Pesticide & 1.950 & 1.150 \\
\hline $\begin{array}{l}\text { Labor cost (tillage, planting, dressing, } \\
\text { weeding, pest controlling, harvest) }\end{array}$ & 7.860 & 7.780 \\
\hline \multicolumn{3}{|l|}{ Total expenses } \\
\hline \multirow[t]{2}{*}{ Earning } & (6.300 kg x Rp. 4.800) & (8.500 kg x Rp. 4.800) \\
\hline & Rp. 30.240 & Rp. 40.800 \\
\hline R/C Ratio & 1.87 & 2.71 \\
\hline
\end{tabular}

Note: land lease excluded

Table 5. Technology Adoption before and after the implementation of jarwo super demo farm

\begin{tabular}{clcc}
\hline No. & \multicolumn{1}{c}{ Components of Technology } & $\begin{array}{c}\text { Before Demo farm } \\
\text { (\% farmers) }\end{array}$ & $\begin{array}{c}\text { After Demo farm } \\
\text { (\% farmers) }\end{array}$ \\
\hline 1 & CSSV usage & 26.70 & 60,00 \\
2 & Straw compost usage & 33,33 & 86,67 \\
3 & RFTK usage & 10,00 & 70,00 \\
4 & Biological fertilizer usage & 6,70 & 66,70 \\
5 & Biological controlling pest & 20,00 & 76,60 \\
6 & Jarwo planting implementation & 6,70 & 60,00 \\
7 & Harvest tool usage & 13,30 & 40,00 \\
\hline
\end{tabular}


Participatory farmers are expected that, with the availability of demo farm, they are able to apply the technology performed in demo farm on the next crop. Besides, they can be resources or pioneers for farmers, around demo farm location, who did not participated in demo farm activities. Non-participatory farmers are expected, after demo farm, to be interested and able to follow the existing technology package. Even though they are not able to apply all, at least they do one of components in jarwo super technology.

Agricultural extension employees as the innovation front liners of jarwo super rice are people who facilitate technology producers (researchers) and users (farmers). With good, proper, cognitive and communicative skills, innovation can be well received by farmers.

\section{Number of Visits}

The strategic location for demo farm activities, directly became a display for farmers and the surrounding community. From the guest book of Mardi Tani Farmer Group and guest book of Agricultural Extension Center in Mojoanyar subdistrict, the number of visits came from farmers around demo farm and other sub districts such as Pungging, Pacet, Bangsal, Ngoro, and Kemlagi. Total visits were 243 farmers and officers.

\section{Technology Adoption}

Dissemination activities of jarwo super increased the adoption of jarwo super technology components. The increasing adoption of jarwo super technology components ranged from $26.7-60 \%$. The largest increase of adoption $(60 \%)$ occurred in components of RFTK and biofertilizer usages (Table 5).

\section{CONCLUSION}

1. Using CSSV through demo farm of jarwo super increases rice productivity between 12.26$32.03 \%$.

2. Adopting jarwo super technology components by farmers shows a noticeable increase before and after demo farm. The highest adoption are on the components of using RFTK and biological fertilizers.

3. Demo farm of jarwo super improves farming efficiency and farmer income.

4. From the activity of jarwo super's demo farm, approximately 25 tons of paddy seed from ES and SS class are obtained.

\section{ACKNOWLEDGEMENT}

We are grateful to farmers of Mardi Tani Farmer Group in Central Sadar Village, Mojoanyar Subdistrict, Mojokerto Regency for their time and patience in contributing to the data collection. We are also thankful to Eni Fidiyawati as a fellow researcher for her support in conducting the study and analyzing data.

\section{REFERENCES}

[1]. Suyamto dan I. N. Widiarta. 2010. Kontribusi Inovasi teknologi dan arah litbang tanaman pangan ke depan. Hal: 115. Dalam Hermanto dan Sunihardi (penyunting). Inovasi Teknologi Berbasis Ketahanan Pangan Berkelanjutan. Puslitbangtan Bogor

[2]. Damardjati, J. S. 2006. Learning from Indonesian experiences in achieve rise self sufficientcy. In rice industry, culture, and environment. ICCR, ICFORD, IAARD. Jakarta.

[3]. Sembiring, $H$ dan Abdulrahman. 2008. Filosofi dan dinamika pengelolaan tanaman terpadu padi sawah. Balai Besar Penelitian Padi. Sukamandi.

[4]. Dinas Pertanian Tanaman Pangan Propinsi Jawa Timur. 2015. Laporan Tahunan 2015.

[5]. Pusat Penelitian dan Pengembangan Tanaman Pangan. 2009. Deskripsi Varietas Unggul Palawija (1918-2009). Bogor.

[6]. BPSB Propinsi Jawa Timur, 2014. Laporan Produksi Benih Beberapa Varietas Padi di Jawa Timur tahun 2013.

[7]. Baehaki S.E, I. Made Jana Mejaya, dan Hasil sembiring. 2012. Implementasi Pengendalian Hama Terpadu (PHT) Dalam Pengelolaan Tanaman Terpadu (PTT) Di Indonesia. Bahan Publikasi Badan Litbang Pertanian

[8]. Badan Litbang Pertanian. 2013. Juknis Pengelolaan Unit Pengelola Benih Sumber Tanaman. Badan Litbang Pertanian. Kementerian Pertanian

[9]. Sitorus, S. R. P., A. Iswati dan Panuju. 2009. Teknik Komoditas Unggulan Pertanian Berdasarkan Potensi Wilayah. Institut Pertanian Bogor.

[10]. Las, I., H. Syahbuddin, E. Surmaini dan A.M. Fagi. 2008. Iklim dan tanaman padi: tantangan dan peluang. Hal 151-189. Dalam. Padi: Inovasi teknologi dan ketahanan pangan. Buku 1. Balai Besar Penelitian Tanaman Padi. Badan Litbang Pertanian. 
[11]. Fagi, A. M., I. Las, H. Pane, S. Abdulrahman, I. N. Widiarta, dan U. S. Nugraha. 2008. Anomali Iklim dan Produksi Padi: Strategi dan Antisipasi Penanggulangan. Balai Penelitian Tanaman Padi. Sukamandi.

[12]. Badan Litbang Pertanian, 2007. Pengelolaan Tanaman Terpadu (PTT) Padi Sawah Irigasi. Petunjuk Teknis Lapang. Badan Penelitian dan Pengembangan Pertanian. Departemen Pertanian. Jakarta

[13]. Badan Litbang Pertanian, 2016. Juknis Teknologi Jajar Legowo Super (draft)

[14]. Dinas Pertanian Tanaman Pangan Propinsi Jawa Timur. 2012. Laporan Tahunan 2012.

[15]. Badan Litbang Pertanian. 2013. Juknis Pengelolaan Unit Pengelola Benih Sumber Tanaman. Badan Litbang Pertanian. Kementerian Pertanian

[16]. Yuniastuti, S., Suwono, R. Budiono, Al.G. Pratomo, E. Korlina, L. Rosmahani, W. Istuti, E. Purnomo dan M. Saeri. 2014. Success story Dampak Penerapan Teknologi Pertanian Spesifik Lokasi di Jawa Timur. BPTP Jawa Timur. 48 hal.

[17]. Mardikanto, T. 1993. Penyuluhan pembangunan pertanian. Sebelas Maret University Press. 